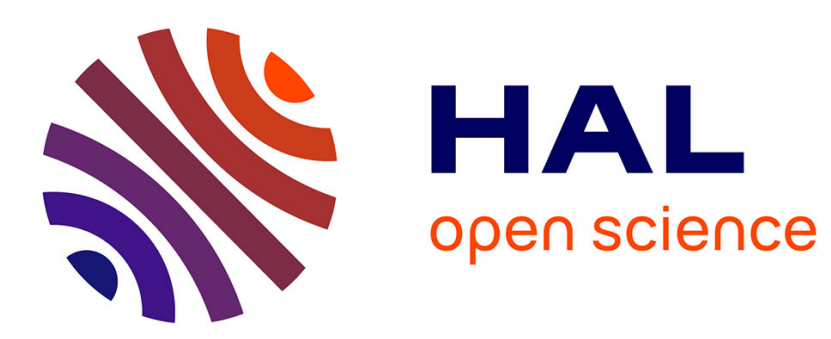

\title{
The non smooth contact dynamics method: recent LMGC90 software developments and application
}

\author{
Frédéric Dubois, Michel Jean
}

\section{To cite this version:}

Frédéric Dubois, Michel Jean. The non smooth contact dynamics method: recent LMGC90 software developments and application. 4th Contact Mechanics International Symposium, Jul 2005, Hannover, Germany. 10.1007/3-540-31761-9_44 . hal-00580798

\section{HAL Id: hal-00580798 \\ https://hal.science/hal-00580798}

Submitted on 17 Nov 2021

HAL is a multi-disciplinary open access archive for the deposit and dissemination of scientific research documents, whether they are published or not. The documents may come from teaching and research institutions in France or abroad, or from public or private research centers.
L'archive ouverte pluridisciplinaire HAL, est destinée au dépôt et à la diffusion de documents scientifiques de niveau recherche, publiés ou non, émanant des établissements d'enseignement et de recherche français ou étrangers, des laboratoires publics ou privés. 


\title{
The non smooth contact dynamic method: recent LMGC90 software developments and application
}

\author{
F. Dubois ${ }^{1}$ and M. Jean ${ }^{2}$
}

1 Laboratoire de Mécanique et Génie Civil, CNRS, Université Montpellier II, France, dubois@lmgc . univ-montp2.fr

2 Laboratoire de Mécanique et d'Acoustique, UPR CNRS, Marseille, France, mjean@imtumn.imt-mrs.fr

The Non Smooth Contact Dynamics method (NSCD) deals with frictional unilateral contact between rigid or deformable bodies. It was originated around 1984 by J.J. Moreau as the Contact Dynamics method $(C D)$. It was extended as the $(N S C D)$ method by M. Jean to deal with more general applications, such as nite element modelling. Numerical applications of the $C D$ method for granular materials are currently customized in C language by J.J. Moreau. The NSCD method has been implemented by M. Jean in a now obsolete fortran77 general purpose software. F. Dubois is the author of a completely remodelled new version $L M G C 90$ written in fortran90, open to research scientists for further developments and applications. This is an open source software governed by a Cecill license (i.e. GPL). In the NSCD method the basic laws such as Coulomb's law and the inelastic shock law are described as non smooth laws in terms of multimappings. The dynamical equation is discretized according to a low order implicit algorithm. The main unknowns are the relative velocities between contactors at some overlapping moments with the time steps (leap frog technique) and the mean reaction impulses during the time step. Assuming provisional values for contacts neighbouring of a given contact, values of the reactions for this given contact are obtained discussing the intersection of the graphs of affine mappings. Values of the reactions are updated, and all contacts are processed successively as long as necessary to obtain a satisfactory convergence. This may be described as a non linear block Gauss Seidel method. The $L M G C 90$ software is dedicated to applications with a large number of $2 \mathrm{D}$ or $3 \mathrm{D}$ contactors. It is a modular software written in fortran90 with an object oriented organisation:

- Mechanical bodies moduli are listing bulk geometric and physical properties, degrees of freedom, descriptors of contactors (or contacting boundaries) attached to the bodies, and the methods to read, write and precompute data. 
- Contact moduli are dedicated to classes of contactors, pairs of a candidate and antagonist contactors. They are listing all local properties, relative velocities, gaps, reaction impulses, interaction laws, detection methods, methods allowing to compute relative velocities from bodies velocities, to compute generalized impulses from reaction impulses.

- A core solver uses the above methods to transfer data to the dynamical algorithm relating bodies velocities and generalized impulses, to the interaction law relating relative velocities and reaction impulses.

Recent developments are concerning core solvers. The non linear block Gauss Seidel method is now available as a shared memory process; a generalized Newton algorithm is implemented. Several interaction laws, so called "Signorini Coulomb derived laws" are implemented, including elastic repell, adhesion and wear laws. The software allows also coupling with thermo elastic problems. Contactors are of the kind: disks, polygons, spheres, polyhedrons, planes, wires, rods, blocks, and a wide variety of 3 or 4 nodes element contactors de ned by nite elements. Applications are concerning: Granular materials, for research purposes such as stability of slopes, segregation, compaction behaviour, or industrial purposes such as railway ballast behaviour. Behaviour of buildings made of blocks, walls, arches, bridges. Dynamic fracture of deformable bodies. Delamination. Biomechanics, micro brilla models, tensegrity cell models.

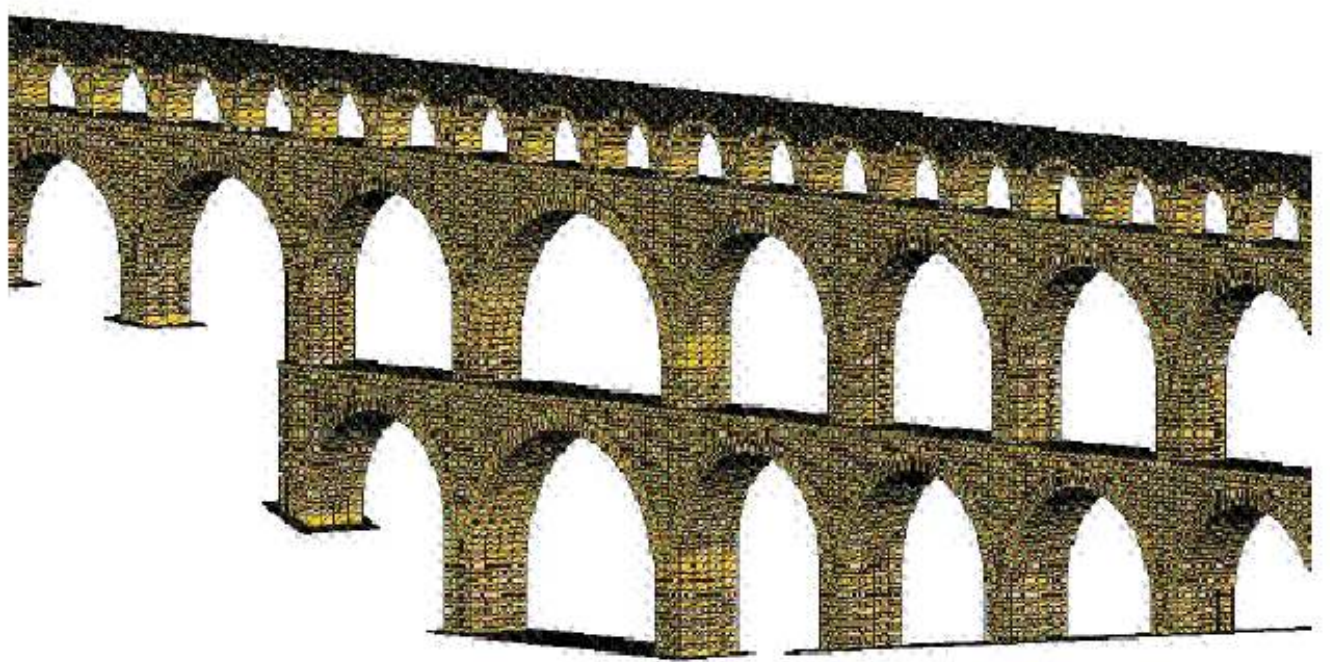

Fig. 1. Masonry: Pont du Gard, 35000 blocks, 250000 contacts, author Brahim Chetouane. 


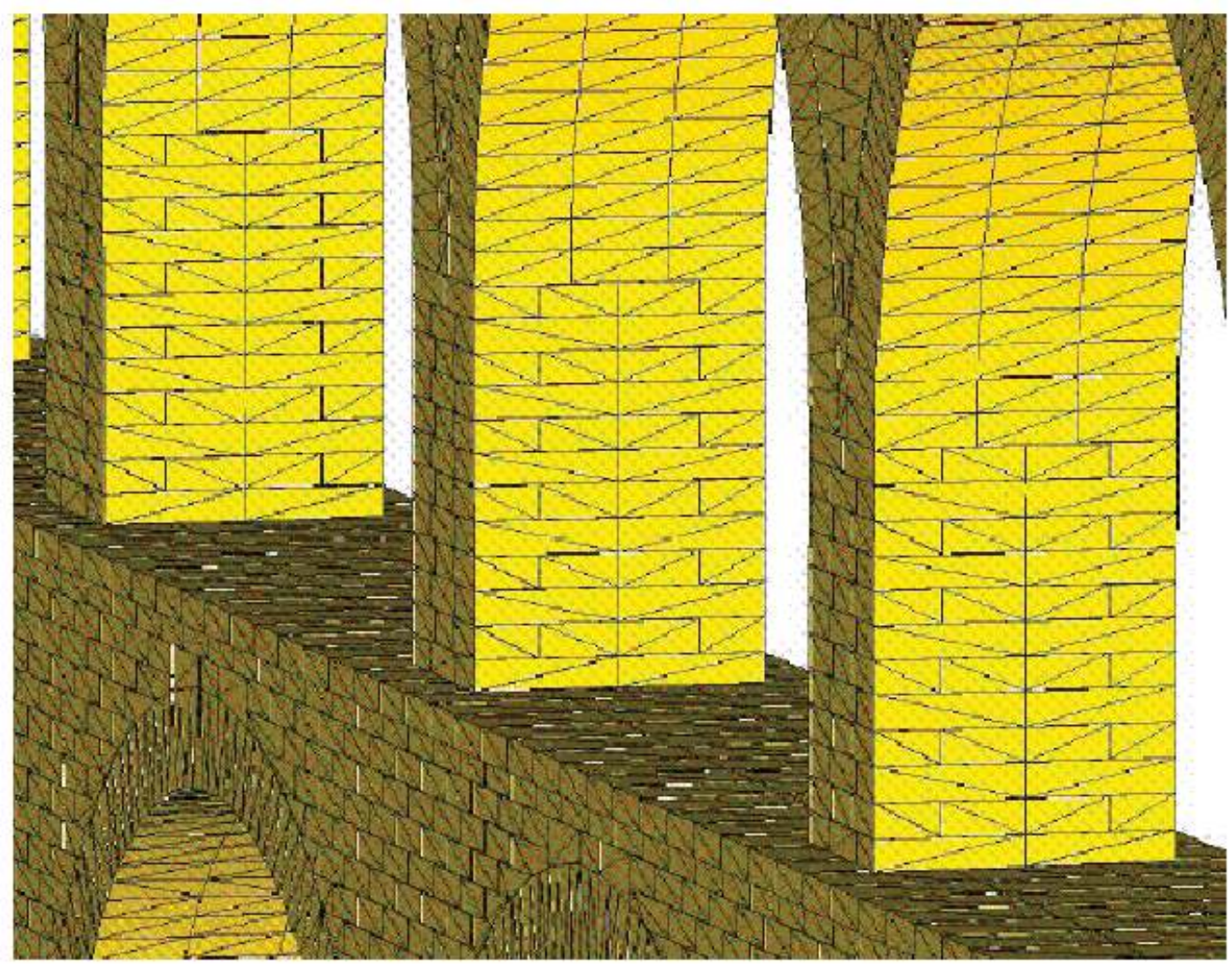

Fig. 2. Masonry: Pont du Gard, 35000 blocks, 250000 contacts, author Brahim Chetouane.

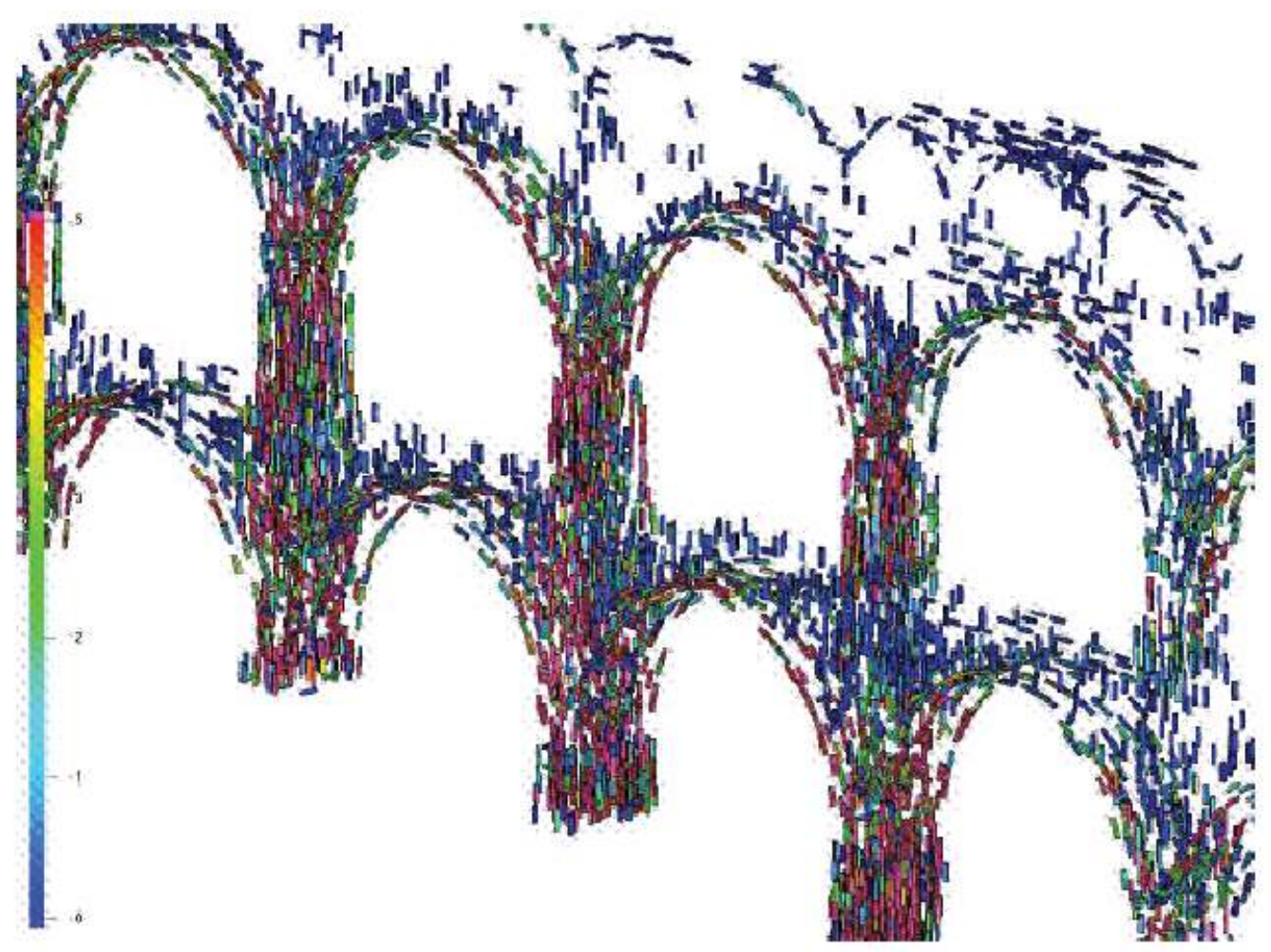

Fig. 3. Pont Du Gard: main stress chains. 


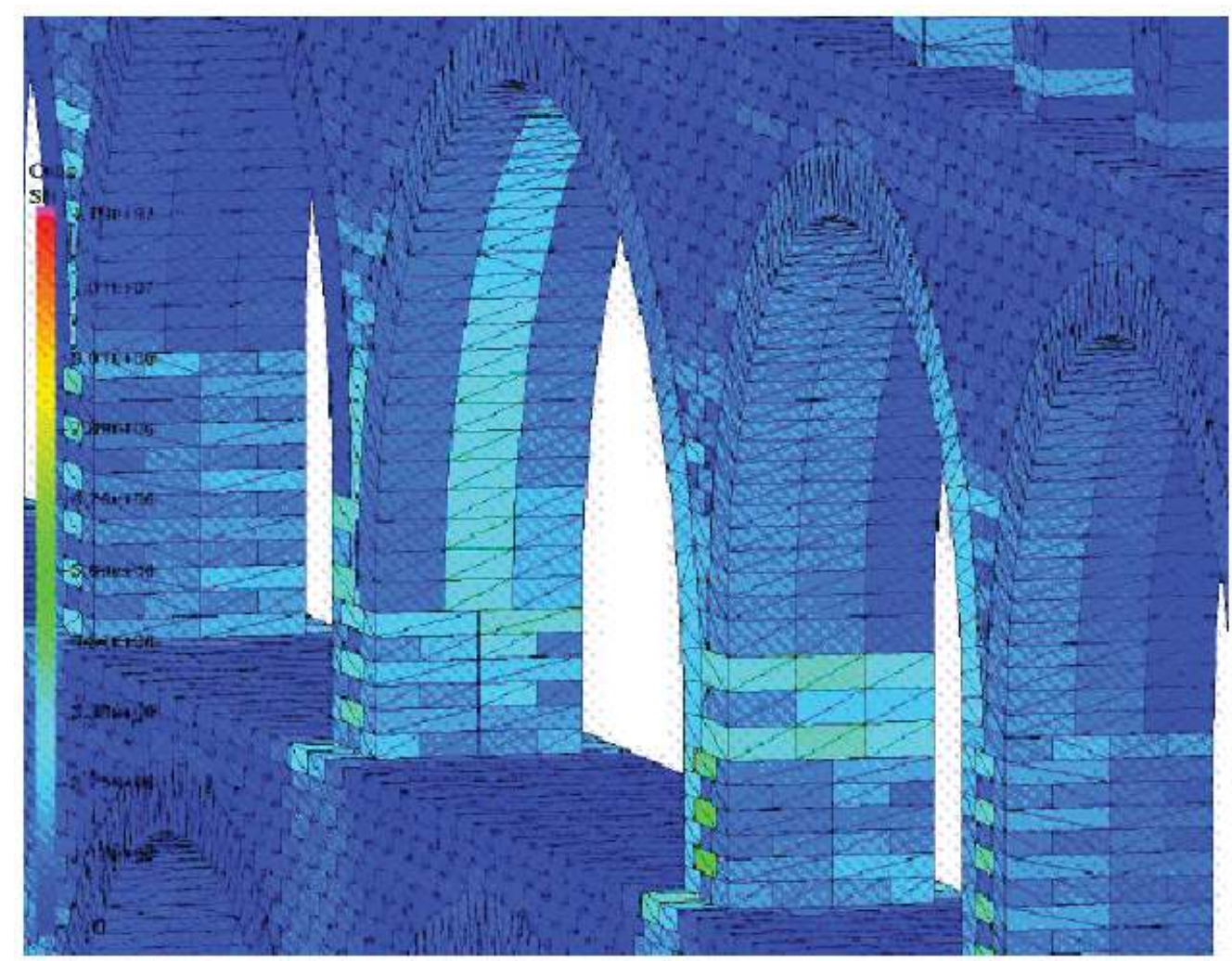

Fig. 4. Pont Du Gard: pressure colored blocks, high pressure pale blue, low pressure dark blue.

\section{References}

1. J.J. Moreau. Unilateral contact and dry friction in nite freedom dynamics, volume 302 of International Centre for Mechanical Sciences, Courses and Lectures. pp. 1-82, J.J. Moreau, P.D. Panagiotopoulos, Springer, Vienna, 1988.

2. J.J. Moreau. Some basics of unilateral dynamics, in F. Pfeiffer, C. Glocker (ed), Unilateral Multibody Dynamics, Kluwer, Dordrect, 1999.

3. M. Jean, J.J. Moreau. Unilaterality and dry friction in the dynamics of rigid bodies collections. In A. Curnier, (ed), Proc. of Contact Mech. Int. Symp., pp. 31-48, 1992.

4. M. Jean. Frictional contact in rigid or deformable bodies: numerical simulation of geomaterials, pp. 463-486, A.P.S. Salvadurai J.M. Boulon, Elsevier Science Publisher, Amsterdam, 1995.

5. M. Jean. The Non Smooth Contact Dynamics Method, Computer Methods in Applied Mechanics and Engineering, special issue on computational modeling of contact and friction, J.A.C. Martins, A. Klarbring (ed), 177, pp. 235-257, 1999.

6. B. Cambou, M. Jean. Micro Mécanique des Matériaux Granulaires. Hermes, Paris, 2001. 